\title{
Is the proportion of the third inter-space that a neuroma occupies a more relevant measurement than the size alone?
}

\author{
Helen Milnes*, Julian Pavier, Simon Stinchcombe \\ From Society of Chiropodists and Podiatrists Annual Conference 2010 \\ Bournemouth, UK. 21-23 October 2010
}

\section{Introduction}

Previous research has failed to show a correlation between the size of a neuroma and the level of pain experienced. The aim of this study was to determine if the proportion of the inter-space that a neuroma occupies has an impact on the level of pain and disability experienced.

\section{Methods}

Forty consecutive subjects with third inter-space neuromas identified on ultrasound were included. The size of the neuroma and the inter-space were measured using ultrasound by the same examiner. Neuroma diameter was measured non-weightbearing plantarly and the inter-space was measured from the dorsal aspect when weightbearing. The proportion of the space occupied by the neuroma was calculated. Visual analogue pain scores and the Manchester-Oxford foot pain and disability questionnaire were collected.

\section{Results}

Analysis of the data collected failed to show any correlations between the proportion of the space the neuroma occupies with either of the outcome measures used. The hypothesis; the greater proportion a neuroma occupies within the inter-space the greater the level of pain and disability experienced can be rejected.

\section{Discussion}

The proportion of the inter-space that is occupied by a neuroma does not correlate to the level of pain and disability experienced.

\footnotetext{
Sherwood Forest Hospitals, Notts, UK
}

C 2010 Milnes et al; licensee BioMed Central Ltd. This is an open access article distributed under the terms of the Creative Commons Attribution License (http://creativecommons.org/licenses/by/2.0), which permits unrestricted use, distribution, and reproduction in any medium, provided the original work is properly cited.
doi:10.1186/1757-1146-3-S1-017

Cite this article as: Milnes et al.: Is the proportion of the third interspace that a neuroma occupies a more relevant measurement than the size alone? Journal of Foot and Ankle Research 2010 3(Suppl 1):017.
Submit your next manuscript to BioMed Central and take full advantage of:

- Convenient online submission

- Thorough peer review

- No space constraints or color figure charges

- Immediate publication on acceptance

- Inclusion in PubMed, CAS, Scopus and Google Scholar

- Research which is freely available for redistribution

Submit your manuscript at www.biomedcentral.com/submit
() Biomed Central 